\title{
SISTEM PAKAR UNTUK MENDIAGNOSA PENYAKIT KULIT PADA KUCING MENGGUNAKAN CERTAINTY FACTOR
}

\author{
Nia Kurniati ${ }^{1}$, Yessy Yanitasari ${ }^{2}$, Dhieka Avrilia Lantana ${ }^{3}$, Inna Sabily Karima ${ }^{4}$, dan \\ Erliyan Redy Susanto ${ }^{5}$ \\ 1nia.kurniati@umi.ac.id, ${ }^{2}$ yessy.yanitasari@gmail.com, ${ }^{3}$ dhiekalantana12@gmail.com, \\ 4innasabilykarima@gmail.com, ${ }^{5}$ redyers@gmail.com \\ ${ }^{1}$ Teknik Informatika, Universitas Muslim Indonesia Makassar, ${ }^{2}$ Teknik Informatika,STMIK Kharisma \\ Karawang. Karawang, ${ }^{3}$ Departemen IImu Komputer FMIPA, Institut Pertanian Bogor, ${ }^{4}$ Departemen IImu \\ Komputer FMIPA, ${ }^{5}$ Teknik Informatika STMIK Teknorat Lampung.
}

\begin{abstract}
Abstrak
Kucing merupakan hewan yang mudah beradaptasi dan dapat menjadi teman baik bagi manusia. Kecerobohan pemilik dalam menjaga dan merawat kucing dapat mengakibatkan kematian bagi kucing. Salah satu penyakit yang sering dijumpai adalah penyakit kulit pada kucing. Pemahaman masyarakat akan penyakit kulit pada kucing masih rendah. Sehingga masih banyak masyarakat yang masih mengandalkan keahlian dari pakar secara manual. Selain itu, biaya untuk pengobatan ke dokter hewan sangatlah mahal dan keberadaan dokter hewan masih sangat sedikit. Kesalahan pemberian obat dapat memperparah kondisi kucing. Solusi dari permasalahan tersebut dapat di bangun melalui sistem pakar Sistem pakar merupakan sistem penalaran yang dapat menentukan jenis penyakit seperti halnya dokter. Penelitian ini menggunakan pendekatan Certainty Factor yaitu pendekatan ketidakpastian. Hasil penelitian menunjukkan tingkat kebenaran, keakuratan dari kemungkinan penyakit kulit pada kucing.
\end{abstract}

Kata kunci: Certainty Factor, Kulit Kucing, Sistem Pakar.

\section{Pendahuluan}

Kucing merupakan hewan yang mudah beradaptasi dan dapat menjadi teman baik bagi manusia. Terdapat 514 kucing yang berada di 11 kelurahan administrative di Kecamatan Bogor Tengah [1]. Pemahaman masyarakat akan penyakit kulit pada kucing masih rendah. Banyak sekali masyarakat masih mengandalkan keahlian dari pakar secara manual. Sehingga biaya yang ditanggung masyarakat cukup mahal dan dilihat dari waktu juga kurang efisien. Biaya untuk pengobatan ke dokter hewan sangatlah mahal dan keberadaan dokter hewan masih sangat sedikit.

Penyakit kulit merupakan penyakit yang paling sering dijumpai pada kucing. Kecerobohan pemilik dalam menjaga dan merawat kucing akan mengakibatkan kematian bagi kucing. Beberapa penyakit pada kucing bahkan ada yang dapat menular dengan cepat pada manusia. Penyakit kulit pada kucing memiliki gejala yang hampir mirip seperti menggaruk dan bulu rontok. Hal tersebut mengkibatkan kesulitan bagi orang awam dalam menentukan penyakit yang diderita kucing. Kesalahan pemberian obat dapat memperparah kondisi kucing. Solusi dari permasalahan tersebut dapat di bangun suatu sistem pakar. Sistem pakar merupakan sistem penalaran yang dapat menentukan jenis penyakit seperti halnya dokter didasarkan pada gejala-gejala yang ada. Sistem pakar adalah sistem komputer berbasis pengetahuan yang terpadu di dalam suatu sistem informasi dasar yang ada, sehingga memiliki kemampuan untuk memecahkan berbagai masalah layaknya seorang pakar [2].

Beberapa penelitian telah dilakukan untuk mendiagnosis penyakit pada kucing. Penelitian sebelumnya membangun sistem pakar untuk mendiagnosis penyakit anemia pada kucing [3]. Dalam penelitian tersebut telah berhasil dibangun sebuah sistem pakar yang disebut FELINE untuk membantu dokter dalam mendiagnosis penyakit anemia pada kucing. Terhadap penyakit kulit pada kucing telah dilakukan penelitian pembangunan sistem pakar menggunakan teknik rule-based [4]. Selain itu, telah dibuat suatu kerangka kerja (framework) untuk pembangunan sistem pakar untuk mendiagnosis penyakit hewan [5]. Ada beberapa pendekatan yang dapat dilakukan untuk membangun sistem pakar. Salah satunya pendekatan ketidakpastian yaitu Certainty Factor yang telah dilakukan pada penyakit kulit pada anjing [6].

Penelitian ini dilakukan untuk memberikan kemudahan bagi mereka yang memelihara kucing agar dapat mendiagnosis penyakit serta solusi yang cepat untuk melakukan tindakan. 
ILKOM Jurnal IImiah Volume 9 Nomor 1 April 2017

\section{Metode}

Tahap-tahap tersebut diselesaian dengan metode penelitian yang dapat dilihat pada Gambar 1 .

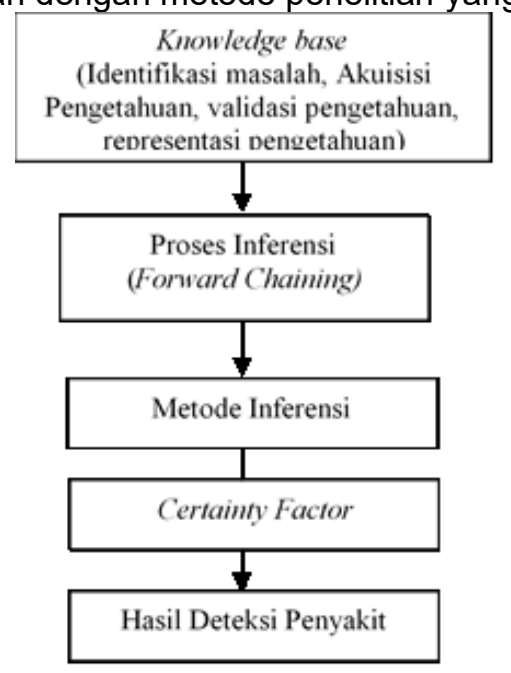

\subsection{Knowledge Base}

Gambar 1. Tahapan Penelitian

Identifikasi permasalahan dalam penelitian ini adalah pembangunan sistem pakar dalam mendiagnosa jenis penyakit kulit pada kucing. Proses yang dilakukan oleh seorang Knowledge engineering [7]. Berikut tahap-tahap proses dari Knowledge engineering:

a. Identifikasi Masalah

Identifikasi masalah merupakan suatu cara bagaimana melihat, menduga, memperkirakan, dan menguraikan serta menjelaskan apa yang menjadi masalah.

b. Akuisisi Pengetahuan

Pada tahap ini Knowledge Engineers (KEs) berusaha menyerap pengetahuan untuk selanjutnya ditransfer ke dalam basis pengetahuan yang diperoleh dari pakar, dilengkapi dengan basis data, buku, laporan penelitian dan pengalaman pengguna [8]. Bahan pengetahuan dapat ditempuh dengan beberapa cara, yaitu, dari buku Norsworthy et. al [9] serta pakar dibidang penyakit kulit kucing.

c. Validasi Pengetahuan

Validasi pengetahuan dilakukan untuk menentukan tingkat keakuratan kebenaran dan keyakinan dari pengetahuan yang diperoleh sebelumnya dengan hasil pengetahuan yang telah diolah.

d. Representasi Pengetahuan

Representasi pengetahuan menggunakan Diagram pohon yang dapat dilihat ada Gambar 3.

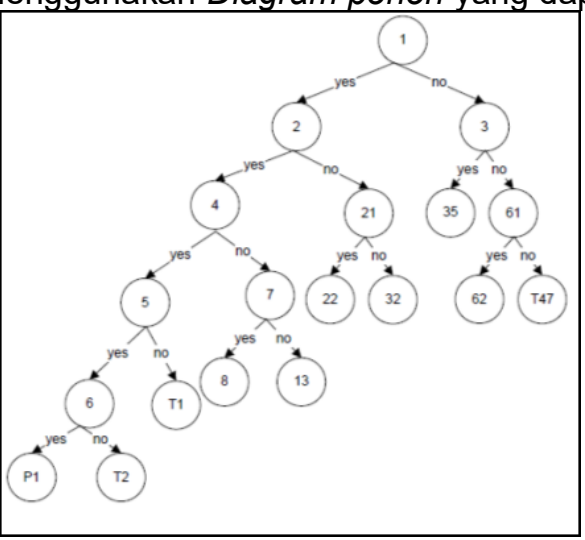

Gambar 3. Representasi menggunakan Diagram Pohon.

Diagram pohon seperti pada Gambar 3 notasi "yes" menandakan bahwa node memenuhi node diatasnya, sedangkan "no" menandakan bahwa node diatanya tidak terpenuhi. Hipotesis P1 akan dicapai jika ada node 1,2,4,5, dan 6 .

2.2 Proses Inferensi (Forward Chaining)

Metode penalaran yang digunakan apabila pengetahuan dipresentasikan untuk mengikuti aturanaturan sistem pakar yaitu dengan menggunakan forward chaining. 


\subsection{Metode Inferensi menggunakan Certainty Factor}

Setelah didapat rule dari proses akuisisi, selanjutnya akan dihitung nilai Certainty Factor dari setiap rule atau fakta yang ada. Penentuan Certainty Factor pada setiap rule terjadi karena pakar mengalami ketidakpastian dalam menentukan jenis penyakit.

Berikut adalah deskripsi dari penggabungan nilai CF pada beberapa kondisi:

1. CF untuk rule premis tunggal

$$
\begin{aligned}
\mathrm{CF}(\mathrm{H}, \mathrm{E}) & =\mathrm{CF}(\mathrm{E})^{*} \mathrm{CF} \text { (rule) } \\
& =\mathrm{CF}(\text { user })^{*} \mathrm{CF}(\text { expert })
\end{aligned}
$$

2. $C F$ untuk rule yang multiple

$$
\begin{aligned}
& \mathrm{CF}(\mathrm{A} \text { AND B })=\text { Minimum }(\mathrm{CF}(\mathrm{a}), \mathrm{CF}(\mathrm{b})){ }^{*} \mathrm{CF}(\text { rule }) \\
& \mathrm{CF}(\mathrm{A} \text { OR B })=\text { Maximum }(\mathrm{CF}(\mathrm{a}), \mathrm{CF}(\mathrm{b})){ }^{*} \mathrm{CF}(\text { rule })
\end{aligned}
$$

3. $C F$ untuk menghasilkan rule gabungan

$$
\begin{aligned}
\text { CF COMBINE(CF1,CF2) } & \\
= & \text { CF } 1+C F 2^{*}(1-C F 1)
\end{aligned}
$$

Dalam penelitian ini nilai CF untuk pakar memiliki rentang 0 sampai 1 dengan ketentuan yang dapat diihat pada Tabel.1. Sedangkan untuk user juga memiliki nilai ketidakpastian yang dapat dilihat pada Tabel 2 Nilai CF untuk User [6].

Tabel 1. Nilai CF untuk pakar

\begin{tabular}{lc}
\hline \multicolumn{1}{c}{ Ketidakpastian } & Certainty Factor \\
\hline Sangat Pasti & 1 \\
Pasti & 0,8 \\
Kemungkinan iya & 0,6 \\
Kemungkinan tidak & 0,4 \\
Pasti tidak & 0 \\
\hline
\end{tabular}

Tabel 2. Nilai CF untuk User

\begin{tabular}{lc}
\hline \multicolumn{1}{c}{ Ketidakpastian } & Certainty Factor \\
\hline Sangat Yakin & 1 \\
Yakin & 0,8 \\
Cukup Yakin & 0,6 \\
Sedikit Yakin/mungkin & 0,4 \\
Tidak & 0 \\
\hline
\end{tabular}

Nilai 0 menunjukkan bahwa pasien tidak mengalami gejala penyakit yang diminta oleh sistem. Semakin banyak pasien yakin bahwa ia memang mengalami gejala tersebut, maka akan semakin besar persentase dari total keyakinan dari hasil yang akan didapatkan.

2.4 Implementasi Sistem

Tahap implementasi dilakukan sesuai dengan perangkat pengembang yang digunakan. Pemilihan perangkat lunak didasarkan atas kesesuaian karakteristik permasalahan yang dikaji [10].

2.5 Pengujian Sistem

Pengujian tidak selalu harus mencakup seluruh permasalahan yang ditangani, tetapi dapat

\begin{tabular}{|c|c|c|c|c|c|c|c|c|c|c|}
\hline No & Kutu & $\begin{array}{c}\text { Nafsu } \\
\text { Makan } \\
\text { berkurang }\end{array}$ & $\begin{array}{c}\text { Lendir } \\
\text { pada } \\
\text { telinga }\end{array}$ & 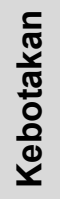 & 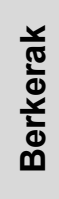 & $\begin{array}{c}\text { Bulatan } \\
\text { merah } \\
\text { pada } \\
\text { kulit }\end{array}$ & $\begin{array}{c}\text { Lendir } \\
\text { sekitar } \\
\text { bulatan }\end{array}$ & $\begin{array}{l}\text { 응 } \\
\dot{d} \\
\text { है } \\
\text { q }\end{array}$ & $\begin{array}{l}\text { Feses } \\
\text { mencret }\end{array}$ & Penyakit \\
\hline 1. & $\mathrm{v}$ & $\mathrm{v}$ & $\mathrm{V}$ & $\mathrm{V}$ & $\mathrm{v}$ & & & & & Otitis Media \\
\hline 2. & & & & V & $\mathrm{v}$ & & & $\mathrm{v}$ & $\mathrm{v}$ & Dermatophytosis \\
\hline 3. & & $\mathrm{v}$ & & V & $\mathrm{v}$ & & & $\mathrm{v}$ & $\mathrm{v}$ & Dermatophytosis \\
\hline 4. & & & & V & $\mathrm{v}$ & & & $\mathrm{v}$ & $\mathrm{v}$ & Dermatophytosis \\
\hline 5. & $\mathrm{v}$ & & & V & $\mathrm{v}$ & & & & & Scabies \\
\hline
\end{tabular}
dilakukan secara modular atau menurut bidang keahlian [10].

3. Hasil dan Pembahasan

Dapat dilihat pada Tabel.3 hasil observasi yang dilakukan pada tahun 2013. Penelitian ini menggunakan algoritma Iterative Dichotomiser 3 (ID3) sebagai pengolahan data.

Tabel.3 Case study 
ILKOM Jurnal Ilmiah Volume 9 Nomor 1 April 2017

\begin{tabular}{|c|c|c|c|c|c|c|c|c|c|c|}
\hline No & Kutu & $\begin{array}{c}\text { Nafsu } \\
\text { Makan } \\
\text { berkurang }\end{array}$ & $\begin{array}{l}\text { Lendir } \\
\text { pada } \\
\text { telinga }\end{array}$ & $\begin{array}{l}\frac{c}{\pi} \\
\frac{1}{\pi} \\
\frac{1}{0} \\
\frac{0}{0} \\
\frac{1}{0}\end{array}$ & $\begin{array}{l}\frac{r}{\pi} \\
\frac{0}{d} \\
\frac{x}{d} \\
\frac{x}{0}\end{array}$ & $\begin{array}{c}\text { Bulatan } \\
\text { merah } \\
\text { pada } \\
\text { kulit }\end{array}$ & $\begin{array}{l}\text { Lendir } \\
\text { sekitar } \\
\text { bulatan }\end{array}$ & 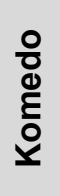 & $\begin{array}{l}\text { Feses } \\
\text { mencret }\end{array}$ & Penyakit \\
\hline 6. & $\mathrm{v}$ & $\mathrm{v}$ & & $\mathrm{V}$ & $\mathrm{v}$ & & \multirow{7}{*}{ v } & & $\mathrm{v}$ & \multirow{7}{*}{$\begin{array}{c}\text { Scabies } \\
\text { Scabies } \\
\text { Ringworm Ragi } \\
\text { Ringworm } \\
\text { Flea } \\
\text { Flea } \\
\text { Tidak Ditemukan } \\
\text { Penyakit }\end{array}$} \\
\hline 7. & v & v & & V & $\mathrm{v}$ & & & & $\mathrm{v}$ & \\
\hline 8. & & v & & V & $\mathrm{v}$ & v & & & \multirow{5}{*}{$\mathrm{v}$} & \\
\hline 9. & & v & & V & $\mathrm{v}$ & v & & & & \\
\hline 10. & v & $\mathrm{v}$ & & V & $\mathrm{v}$ & & & & & \\
\hline 11. & v & & & V & $v$ & & & & & \\
\hline 12. & & v & & & & & & & & \\
\hline
\end{tabular}

Decision tree dibangun berdasarkan besarnya Gain yang diperoleh pada tiap atribut. Atribut yang digunakan dalam pembangunan decision tree adalah gejala. Gejala terdiri dari kutu, nafsu makan berkurang, lendir pada telinga, berkerak, kebotakan, bulat merah, lendir di sekitar bulatan merah, komedo dan feses mencret. Atribut yang terpilih sebagai akar, didasarkan pada nilai Gain tertinggi dari atribut-atribut yang ada. Gain dihitung dalam persamaan 3.

$\operatorname{Gain}(S, A)=\operatorname{Entropy}(S)-\sum_{i=1}^{n} \frac{\left|S_{i}\right|}{|S|} \operatorname{Entropy}\left(S_{i}\right)$

Dengan,

$\begin{array}{llll}S & \text { : Himpunan kasus } & |S i| & : \text { Jumlah kasus pada partisi ke } i \\ A & : \text { Atribut } & |S| & \text { : Jumlah kasus dalam } S \\ n & \text { : Jumlah partisi atribut } A & & \end{array}$

Sedangkan perhitungan nilai entropy digunakan dalam persamaan 4.

$\operatorname{Entropy}(S)=\sum_{i=1}^{n}-p i * \log _{2} p_{i}$

Dengan,
$S \quad:$ Himpunan Kasus
$n \quad$ : Jumlah partisi $S$
A : Fitur
pi : Proporsi dari Si terhadap $S$

Pembentukan decision tree menggunakan algoritma ID3. Penghitungan Gain untuk masing-masing atribut dilakukan menggunakan persamaan.3 dan persamaan.4 Hasil ditunjukkan pada Tabel 4.

Tabel 4. Perhitungan Node 1

\begin{tabular}{|c|c|c|c|c|c|c|c|c|c|c|c|}
\hline & & $\mathbf{S}$ & $S_{1}$ & $\mathrm{~S}_{2}$ & $\mathrm{~S}_{3}$ & $\mathrm{~S}_{4}$ & $S_{5}$ & $\mathrm{~S}_{6}$ & $S_{7}$ & Entropy & Gain \\
\hline TOTAL & & 12 & 1 & 2 & 3 & 1 & 1 & 2 & 1 & 2,626 & \\
\hline \multirow[t]{3}{*}{ Kutu } & & & & & & & & & & & 1,761 \\
\hline & $\mathrm{Ya}$ & 6 & 1 & 0 & 3 & 0 & 0 & 2 & 0 & 1,229 & \\
\hline & Tidak & 6 & 0 & 3 & 0 & 3 & 0 & 0 & 0 & 0,5 & \\
\hline \multirow{3}{*}{$\begin{array}{l}\text { Nafsu makan } \\
\text { kurang }\end{array}$} & & & & & & & & & & & 1,148 \\
\hline & $\mathrm{Ya}$ & 7 & 1 & 1 & 2 & 1 & 1 & 1 & 0 & 1,925 & \\
\hline & Tidak & 5 & 0 & 2 & 1 & 0 & 0 & 1 & 1 & 1,327 & \\
\hline \multirow[t]{3}{*}{$\begin{array}{c}\text { Lendir pada } \\
\text { Telinga }\end{array}$} & & & & & & & & & & & 1,461 \\
\hline & $\mathrm{Ya}$ & 1 & 1 & 0 & 0 & 0 & 0 & 0 & 0 & 0,299 & \\
\hline & Tidak & 11 & 0 & 3 & 3 & 1 & 1 & 2 & 1 & 2,327 & \\
\hline \multirow[t]{3}{*}{ Botak } & & & & & & & & & & & 1,61 \\
\hline & $\mathrm{Ya}$ & 11 & 1 & 3 & 3 & 1 & 1 & 2 & 0 & 2,327 & \\
\hline & Tidak & & 0 & 0 & 0 & 0 & 0 & 0 & 1 & 0 & \\
\hline \multirow[t]{3}{*}{ Kerak } & & & & & & & & & & & 1,461 \\
\hline & $\mathrm{Ya}$ & 11 & 1 & 3 & 3 & 1 & 1 & 2 & 0 & 2,327 & \\
\hline & Tidak & 1 & 0 & 0 & 0 & 0 & 0 & 0 & 1 & 0,299 & \\
\hline Bulat merah & & & & & & & & & & & 1,461 \\
\hline
\end{tabular}


ILKOM Jurnal IImiah Volume 9 Nomor 1 April 2017

\begin{tabular}{cccccccccccc}
\hline & & $\mathbf{S}$ & $\mathbf{S}_{1}$ & $\mathbf{S}_{2}$ & $\mathbf{S}_{3}$ & $\mathbf{S}_{4}$ & $\mathbf{S}_{5}$ & $\mathbf{S}_{6}$ & $\mathbf{S}_{7}$ & Entropy & Gain \\
\hline & Ya & 2 & 0 & 0 & 0 & 1 & 1 & 0 & 0 & 0,597 & \\
& Tidak & 10 & 1 & 3 & 3 & 0 & 0 & 2 & 1 & 2,028 & \\
\hline Lendir Merah & & & & & & & & & & & \\
& Ya & 1 & 0 & 0 & 0 & 0 & 1 & 0 & 0 & 0 & 1,61 \\
& Tidak & 11 & 1 & 3 & 3 & 1 & 0 & 2 & 1 & 2,327 & \\
\hline komedo & & & & & & & & & & & 1,461 \\
& Ya & 3 & 0 & 3 & 0 & 0 & 0 & 0 & 0 & 0,5 & \\
& Tidak & 9 & 1 & 0 & 3 & 1 & 1 & 2 & 1 & 2,126 & \\
meses & & & & & & & & & & & 1,263 \\
& & & & & & & & & & & \\
& Ya & 6 & 0 & 3 & 2 & 0 & 0 & 1 & 0 & 1,229 & \\
& Tidak & 6 & 1 & 0 & 1 & 1 & 1 & 1 & 1 & 1,792 & \\
\hline
\end{tabular}

Keterangan :

$\mathrm{S}=$ Jumlah Kasus

$\mathrm{S}_{1}=$ Otitis media

$\mathrm{S}_{2}=$ Dermatophytosis

$\mathrm{S}_{3}=$ Scabies

$\mathrm{S}_{4}=$ Ringworm Ragi

$$
\begin{aligned}
& \mathrm{S}_{5}=\text { Ringworm } \\
& \mathrm{S}_{6}=\text { Flea } \\
& \mathrm{S}_{7}=\text { Tidak ditemukan penyakit } \\
& \mathrm{Y}=\text { Ya } \\
& \mathrm{T}=\text { Tidak }
\end{aligned}
$$

Baris TOTAL kolom Entropy pada Tabel.4 diperoleh dari persamaan 4. Sementara itu nilai Gain pada baris Kutu dihitung dengan menggunakan persamaan 3, sebagai berikut :

$$
\begin{aligned}
& \operatorname{Gain}(\text { TOTAL,Kutu })=\operatorname{Entropy}(\text { TOTAL })-\sum_{i=1}^{n} \frac{\mid \text { Kutu } \mid}{\mid \text { Total } \mid} \text { Entropy }\left(\text { Outlook }_{i}\right) \\
& \begin{aligned}
\operatorname{Gain}(\text { TOTAL, Kutu }) & =2,626-\left(\left(\frac{6}{12} * 1,229\right)+\left(\frac{6}{12} * 0,5\right)\right) \\
& =1,761
\end{aligned}
\end{aligned}
$$

Hasil pada Tabel 4 dapat diperoleh bahwa atribut dengan Gain tertinggi adalah Kutu yaitu sebesar 1,761. Dengan demikian Kutu dapat menjadi node akar. Ada 2 nilai atribut dari Kutu yaitu "Ya" dan "Tidak". Kedua nilai atribut tersebut, nilai atribut "Ya" dan "Tidak" masih perlu dilakukan perhitungan lagi. Decision tree yang dibangun menggunakan bantuan tools WEKA. Keseluruhan hasil decision tree dapat dilihat pada Gambar 4.

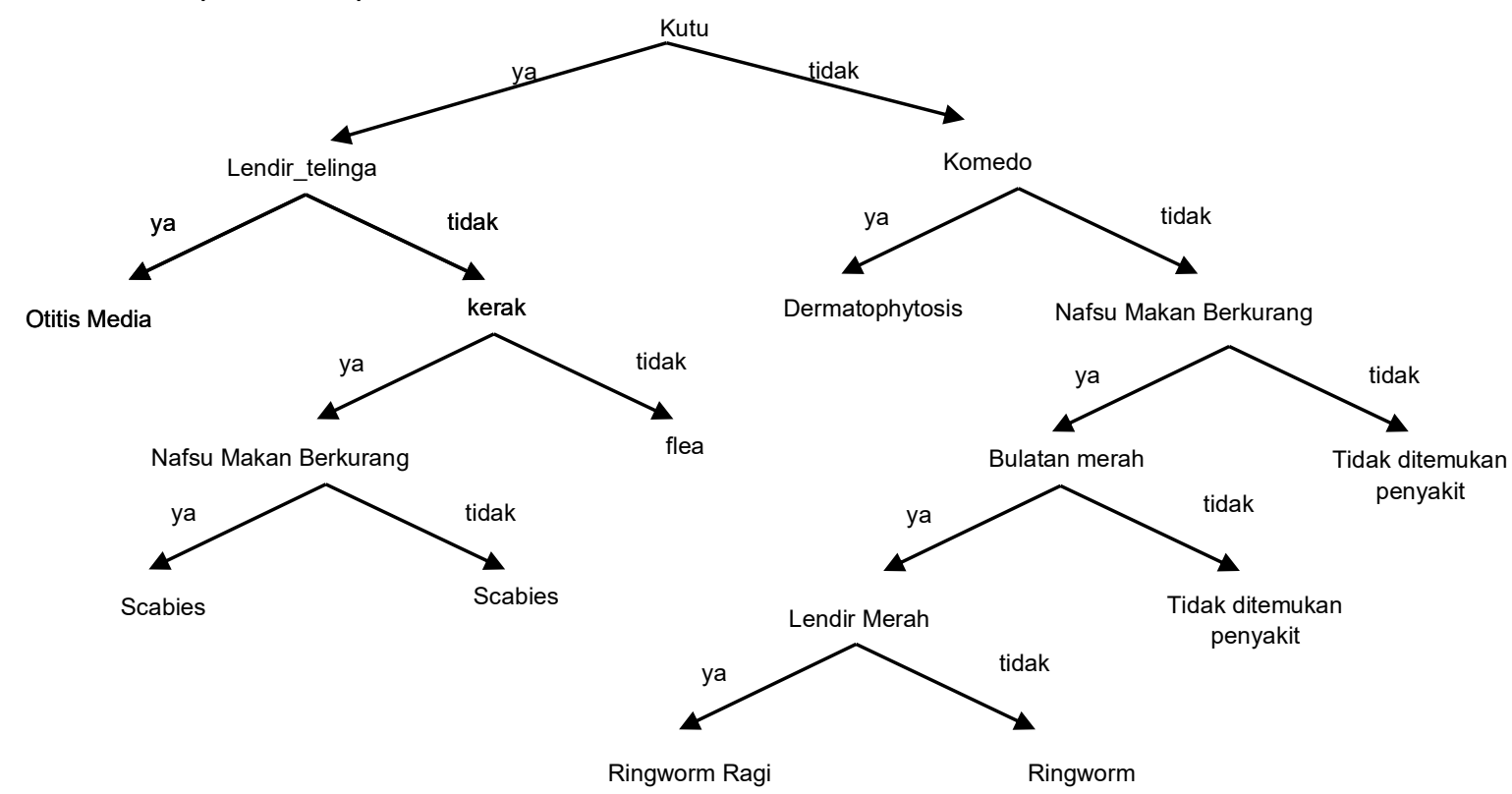

Gambar 4. Decision tree Sistem Pakar Kulit Kucing 
ILKOM Jurnal IImiah Volume 9 Nomor 1 April 2017

\subsection{Representasi Pengetahuan}

Representasi pengetahuan yang digunakan dalam penelitian ini adalah dengan menggunakan Kaidah Produksi, kaidah ini dapat dikatakan sebagai hubungan implikasi dua bagian, yaitu: bagian premis (jika) dan bagian konklusi (maka) (If_Then). Apabila bagian premis dipenuhi maka bagian konklusi juga akan bernilai benar. Representasi pengetahuan ini berfungsi untuk menentukan proses pencarian atau menentukan kesimpulan akhir yang akan didapat. Berdasarkan decision tree penyakit yang telah dibangun pada Gambar 4 maka dapat disimpulkan terdapat 7 aturan atau rule. Dalam pemahaman dasar dan dengan sistem yang sangat dasar, yaitu bagaimana mendiagnosa suatu penyakit berdasarkan gejalanya maka operator logika yang akan digunakan adalah operator logika AND. Dapat disimpulkan ada 7 aturan atau rule yang bisa dijelaskan pada Tabel 5.

\section{Tabel 5. Daftar Aturan Diagnosa}

\begin{tabular}{cl} 
No & \multicolumn{1}{c}{ Aturan } \\
\hline r1 & IF terdapat kutu AND lendir di telinga THEN Otitis Media \\
r2 & IF terdapat kutu AND terdapat kerak AND nafsu makan berkurang \\
& THEN Scabies \\
r3 & IF terdapat kutu AND terdapat kerak THEN Scabies \\
r4 & IF terdapat kutu THEN Flea \\
r5 & IF terdapat Komedo THEN Dermatophytosis \\
r6 & IF nafsu makan berkurang AND terdapat bulat merah THEN Ringworm \\
r7 & IF nafsu makan berkurang AND terdapat bulat merah AND lendir merah THEN \\
& Ringworm Ragi \\
\hline
\end{tabular}

\subsection{Hasil Pendeteksian Menggunakan Certainty Factor}

Certainty Factor (CF) merupakan salah satu teknik untuk mengatasi ketidakpastian dalam pengambilan keputusan. Setelah didapatkan rule dari diagram pohon maka dilakukan perhitungan CF dengan langkah berikut:

1. Identifikasi rule

Rule 1.

IF nafsu makan berkurang

AND terdapat bulat merah

AND lendir merah

THEN Ringworm Ragi

2. Mengubah bentuk multiple rule menjadi single rule dan menentukan CF dari pakar serta user.

Rule 1.1

IF nafsu makan berkurang THEN Ringworm Ragi

Rule 1.2

IF terdapat bulat merah THEN Ringworm Ragi

Rule 1.3

IF lendir merah THEN Ringworm Ragi

CF dari pakar adalah sebagai berikut:

1. CFpakar (nafsu makan berkurang) $=0,6$

2. CFpakar (bulat merah) $=0,8$

3. CFpakar (lendir merah) $=0,8$

User memberikan pernyataan sebagai berikut:

Nafsu makan berkurang: Mungkin =0,4

Bulat merah: Sangat yakin $=1$

Lendir merah: Yakin $=0,8$

Kemudian hitung nilai CF antara pakar dengan user dengan menggunakan persamaan:

$\mathrm{CF}(\mathrm{H}, \mathrm{E}) \quad=\mathrm{CF}(\mathrm{E})^{\star} \mathrm{CF}($ rule $)$

$=\mathrm{CF}$ (user) ${ }^{\star} \mathrm{CF}$ (expert)

CF $1.1=0,6 * 0,4=0,24$

CF $1.2=0,8 * 1=0,8$

CF $1.3=0,8 * 0,8=0,64$

3. Menggabungkan nilai CF

CF yang telah didapat untuk masing-masing rule digabungkan berdasarkan persamaan.1 dan persamaan 2:

CF Gabungan (CF1,CF2) = CF1 + CF2*(1-CF1), sehingga langkah-langkahnya sebagai berikut:

1. Gabungkan CF1.1 dengan CF1.2

$$
\begin{aligned}
\text { CFgabungan (CF1.1, CF1.2) } & =0,24+0,8^{*}(1-0,24) \\
= & 0,848
\end{aligned}
$$


ILKOM Jurnal IImiah Volume 9 Nomor 1 April 2017

2. Gabungkan CFgab dengan CF1.3

$$
=\text { CFgab }
$$

$$
\begin{aligned}
\text { CFgabungan (CFgab, CF1.3) } & =0,848+0,64^{*}(1-0,848) \\
& =0,945 \\
& =\text { CFgabungan * } 100 \% \\
& =0,945^{*} 100 \% \\
& =94,5 \%
\end{aligned}
$$

3. Kesimpulan hasil diagnosis

Hasil persentase di atas dapat dinyatakan bahwa tingkat kepercayaan sistem terhadap penyakit Ringworm Ragi sebesar $94,5 \%$ dengan mempertimbangkan jawaban yang diberikan oleh user.

\subsection{Implementasi Sistem}

Sistem pertama kali akan menampilkan pertanyaan yang menjadi root dalam decision tree yang ditunjukkan pada Gambar 5. Lima pilihan dari jawaban yang tersedia yaitu: sangat yakin, yakin, cukup yakin, mungkin dan tidak. Setiap pilihan jawaban memiliki kualitas yang akan digunakan dalam proses perhitungan masing-masing metode. Jawaban "Tidak" berarti kucing tidak mengalami gejala yang diminta oleh sistem. Semakin tinggi keyakinan pengguna terhadap suatu gejala maka akan semakin tinggi tingkat kepastian suatu penyakit yang akan dihasilkan.

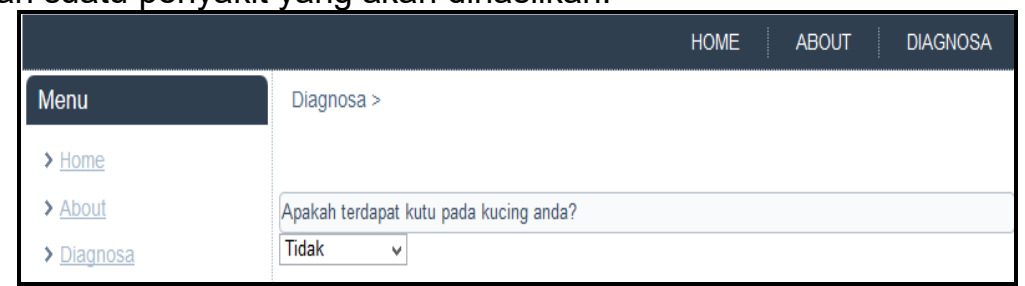

Gambar 5. Pertanyaan pertama pada system

Pada Gambar 6 menunjukkan bagaimana sistem dapat memperoleh hasil diagnosis.

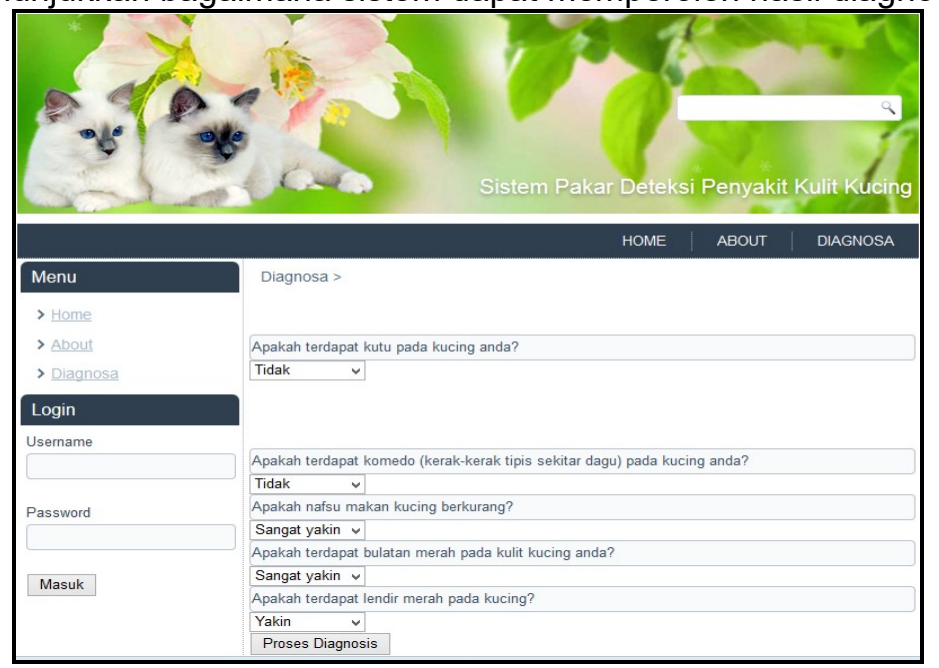

Gambar 6. Proses sistem mengdiagnosis Penyakit

\section{Kesimpulan dan saran \\ Kesimpulan}

Penelitian ini menghasilkan kesimpulan sebagai berikut:

1. Sistem aplikasi sistem pakar ini telah dilakukan pengujian untuk mendiagnosa penyakit kulit pada kucing

2. Sistem ini dirancang dengan menggunakan kaidah produksi yang yang diharapkan bisa Saran mengukur tingkat kepercayaan user terhadap sistem.

Pada penelitian ini perlu dilakukan update data dan penambahan case study secara rutin. 


\section{ILKOM Jurnal IImiah Volume 9 Nomor 1 April 2017}

\section{Ucapan Terima Kasih}

Penulis mengucapkan terima kasih kepada Ibu Dr Tris, selaku pakar penyakit kulit Kedokteran Hewan IPB Bogor.

\section{Daftar Pustaka}

[1] Aditya N. 2006. Keragaman Kucing (Felis Domesticus) Di Kecamatan Bogor Tengah Berdasarkan Karakter Morfologi. .[skripsi]. Departemen Biologi. FMIPA IPB. Bogor

[2] Marimin, 2002. Teori dan Aplikasi Sistem Pakar Dalam Teknik Manajerial. IPB Press. Bogor. Indonesia.

[3] Wooldridge M, O'Hare G, Elks R. 1991. FELINE - A Case Study in the Design and Implementation of a Co-operating Expert System. In Proceedings of the Eleventh European Conference on Expert Systems and Their Applications.

[4] Samat. 2010. Checking Cat Diseases Symptoms System Using Rule-Based Technique. Thesis. Faculty of Systems Computer \& Software Engineering. University Malaysia Pahang

[5] Saurkar A.V, Watane, H.N, 2012, An Expert Syatem For Diseases Diagnosis in Pet, Advances in Medical Informatics, India.

[6] Setyarini E, Putra D, Purnawan A. 2013. The Analysis of Comparison of Expert System of Diagnosing Dog Disease by Certainty Factor Method and Dempster-Shafer. International Journal of Computer Science Issues, Vol. 10, Issue 1, No 2.

[7] Turban, E., Aronson, J.E. (2005). Decision support systems and Intelligent System, 7th. Edition; Prentice Hall International Edition, New Jersey.

[8] Efraim Turban, Decision Support and Expert Systems: Management Support Systems.,New York, Macmillan Publishing Company, 1993.

[9] Gary D, Mitchell A, Sharon Fooshee Grace, larry P. Tilley: The Feline Patient Essential of Diagnosos and Treatment, second Edition.

[10] Marimin. 2009. Teori dan Aplikasi Sistem Pakar dalam Teknologi Manajerial. Bogor: Institut Pertanian Bogor Press. 